\title{
Determinants of tourism flows in Small Island Developing States (SIDS)
}

\author{
Pavla Vítová \\ Department of Development \& Environmental Studies, Faculty of Science, Palacký \\ University Olomouc, Czech Republic \\ pavla.vitova@upol.cz \\ Jaromír Harmáček \\ Department of Development \& Environmental Studies, Faculty of Science, Palacký \\ University Olomouc, Czech Republic \\ jaromir.harmacek@upol.cz (corresponding author)

\section{Zdeněk Opršal} \\ Department of Development \& Environmental Studies, Faculty of Science, Palacký \\ University Olomouc, Czech Republic \\ zdenek.oprsal@upol.cz
}

\begin{abstract}
This paper analyses factors affecting arrivals of international tourists into countries denoted as Small Island Developing States (SIDS). These destinations are paired to all potential countries of origin for which the data was available in the UNWTO database for at least one year over the studied period 1995-2014. The dynamic panel data regression techniques within the gravity approach scheme are applied to identify the significance and importance of different factors of international tourist arrivals into SIDS. These factors are subsequently compared in terms of their significance and relevance across the three geographic sub-regions of SIDS. The results show that tourism flows into SIDS are highly persistent. They depend on the accessibility of destinations, tourism infrastructure development, political stability, and levels of economic development of destinations as well as countries of origin. Exchange rate, weather, and language and historical (colonial) links also play significant roles. The regional comparison reveals that the significance and importance of these factors among the three subregions vary only modestly.
\end{abstract}

Keywords: dynamic panel data regression, gravity model, international tourist arrivals, islands, Small Island Developing States (SIDS), tourism flows

https://doi.org/10.24043/isj.90 • Received October 2018, accepted May 2019

C 2019-Institute of Island Studies, University of Prince Edward Island, Canada. 


\section{Introduction}

Development opportunities of islands, and especially small islands, are constrained by limited local assets and resource endowments (Baldacchino, 2019). Their economies are often largely dependent on mainland countries. While some islands-especially those which are components of mainland states - can rely on financial and other support from their respective metropolis, the issue is much more challenging for the independent small island states (Baldacchino \& Hepburn, 2012). Their small size of domestic markets, limited economic diversification, and relative geographic isolation represent serious impediments to international trade and integration into the world economy (UNWTO, 2017; Briguglio, 1995; Vanegas et al., 2003). Moreover, these factors are often combined with proneness to natural disasters and ongoing climate change, thus lowering the incomes of some small island states (Briguglio, 1995; Pelling \& Uitto, 2001; Turvey, 2009). Nevertheless, island economies can benefit from external sources, which frequently take the form of international tourism revenues or foreign aid. Research into international tourism in small island states should thus represent one of the island studies' priority areas.

The importance of tourism for small islands has been noted by several authors, but mostly from the perspective of an individual island destination (for instance LedesmaRodríguez et al., 2001; Cassidy \& Brown, 2010; Prideax \& McNamara, 2012; Sharpley, 2014; Cañizares et al., 2015) or a region (typically islands in the Caribbean - see Archibald \& LaCorbiniere, 2008; Laframboise et al., 2014). The contribution of tourism for economic growth and development is particularly acknowledged with regard to the Small Island Developing States (SIDS) (UNWTO, 2014) and is recognised by governments and administrations of the majority of SIDS, especially those that are dependent on tourism in terms of its share of exports and contribution to GDP. Tourism is also significant for employment as it generates jobs opportunities for islanders (UNWTO, 2014). In the context of the aforementioned facts, it seems surprising that there is a lack of research addressing factors of international tourism for SIDS as a specific group of countries. Our research aims to fill this gap and contribute mainly to theoretical knowledge in this field as well as to provide some basis for policymakers.

To achieve these objectives we need to know what determines tourism demand across SIDS. Therefore, we ask the principal research question: What are the factors significantly influencing tourist arrivals into SIDS? Additionally, to offer a regional perspective, we compare these factors among the three different geographical groups of SIDS: the Caribbean; the Pacific; and the Atlantic Ocean, Indian Ocean, Mediterranean, and the South China Sea (AIMS). We use dynamic panel regression techniques within the gravity model approach to explain the determinants of tourism flows into SIDS and to compare the determinants among the three regional groups of SIDS.

The rest of the article is organised as follows. In section two, we briefly describe SIDS, then we focus on the literature review related to tourism demand analyses (also applied to SIDS) as well as summarise the gravity approach (also with some applications to tourism). In section three, we present our data and the variables we work with. We also introduce and discuss our estimation procedure for the gravity model approach. In section four, we describe the analysis and present our results. The results and the methods (including the limitations of 
our research) as well as some threats posed by unregulated mass tourism are discussed in section five, while section six concludes.

\section{Literature review}

The group of Small Island Developing States (SIDS) was created in 1992 at the Earth Summit in Rio de Janeiro and two years later, in 1994, the first conference focused specifically on SIDS was held in Barbados. The Barbados Programme of Action (BPOA) stressed that tourism represented a significant development opportunity for SIDS (United Nations, 1994). In 2001, further institutionalisation of SIDS was supported by the establishment of the UN Office of the High Representative for the Least Developed Countries, Landlocked Developing Countries, and Small Islands Developing States (UN-OHRLLS). This office then created the official list of SIDS, which currently includes 58 countries: 38 politically independent states and 20 dependent territories. The independent SIDS (with the exception of Bahrain) formed the Alliance of Small Island States (AOSIS) with five dependent territories now as observers. The aim of the alliance is to represent and support interests of SIDS at the UN (AOSIS, 2015). SIDS are concentrated in two geographical areas (the Caribbean and the Pacific) but are formally classified into three regional groups. The most SIDS are found in the Caribbean (29); followed by the Pacific (20); and then the Atlantic Ocean, Indian Ocean, Mediterranean, and the South China Sea (AIMS) (9). Table 1 shows the regional distribution of SIDS that we have adopted in our study.

Table 1: Geographic distribution of SIDS (with some other features noted). Source: Authors, based on UN-OHRLLS (2017).

\begin{tabular}{|c|c|}
\hline Caribbean & 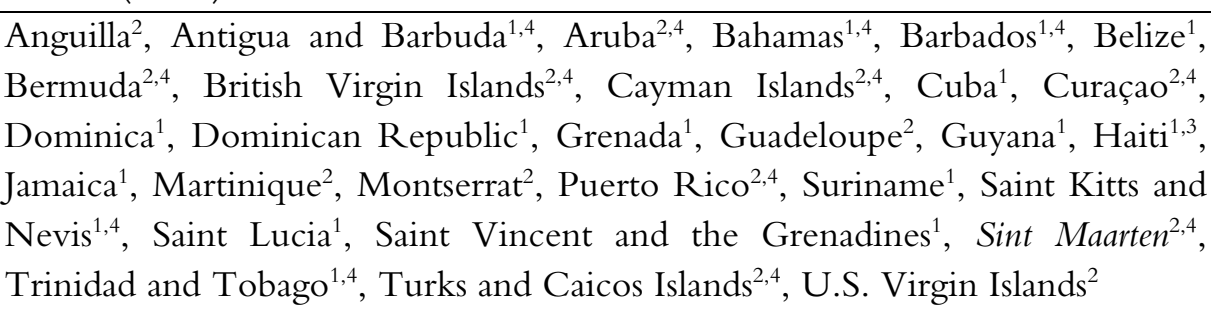 \\
\hline Pacific & $\begin{array}{l}\text { American Samoa }{ }^{2} \text {, Cook Islands }{ }^{2} \text {, Fiji }{ }^{1} \text {, French Polynesia }{ }^{2,4}, \text { Guam }^{2,4} \text {, Kiribati }{ }^{1,3} \text {, } \\
\text { Marshall Islands }{ }^{1} \text {, Federated States of Micronesia }{ }^{1} \text {, Nauru }{ }^{1} \text {, Niue }{ }^{2} \text {, New } \\
\text { Caledonia }^{2,4}, \text { Palau }^{1,4} \text {, Papua New Guinea }{ }^{1}, \text { Samoa }^{1}, \text { Northern Mariana Islands }^{2,4} \text {, } \\
\text { Solomon Islands }^{1,3} \text {, Timor-Leste }{ }^{1,3} \text {, Tonga }{ }^{1} \text {, Tuvalu }{ }^{1,3} \text {, Vanuatu }{ }^{1,3}\end{array}$ \\
\hline AIMS & $\begin{array}{l}\text { Bahrain }^{1,4} \text {, Cabo Verde }{ }^{1} \text {, Comoros }{ }^{1,3} \text {, Guinea-Bissau }{ }^{1,3} \text {, Maldives }{ }^{1} \text {, Mauritius }{ }^{1} \text {, } \\
\text { Seychelles }^{1,4} \text {, Singapore }{ }^{1,4} \text {, Sao Tome a Principe }{ }^{1,3}\end{array}$ \\
\hline
\end{tabular}

Notes: ${ }^{1} \mathrm{UN}$ member states; ${ }^{2}$ Dependent territories; ${ }^{3}$ Least Developed Countries; ${ }^{4}$ Highincome countries. The two countries in italics (Nauru and Sint Maarten) were not included in our analysis due to a complete absence of data in the UNWTO database.

It can be seen from above that SIDS represent a heterogeneous group of countries with specific development challenges as well as opportunities, among which the significant tourism potential is often included. According to UNWTO (2017), SIDS share three key features that make them unique from a development perspective. Firstly, SIDS are small which leads to an increased pressure on their environments. The smallness of SIDS also means a limited 
diversification of the economy. Secondly, they are remote and isolated which constrains international trade on the one hand but helps to preserve unique natural and cultural diversity on the other hand. Thirdly, coastal environments are a typical feature of SIDS. While this is relevant for the development of tourism, the coastal environments are fragile and vulnerable to extreme climate situations and to climate changes in general.

Although the level of economic and social development varies among SIDS (see Table 1), for the majority of them tourism is significant in terms of exports and contribution to the economy, as is shown by the shares of tourism relative to GDP and exports (with some exceptions, such as Papua New Guinea and Suriname). The average total contribution of tourism to GDP in 2015 was $35.6 \%$ (the median value was $25.6 \%$ ), with these shares varying from the low in Papua New-Guinea (2\%) to the high in British Virgin Islands (94.3\%) (WTTC, 2017b). The average share of international tourism receipts in exports for SIDS in 2015 was 42.2\% (median 36.3\%), with the highest value in Palau (87.1\%) and the lowest in Papua New Guinea (0.02\%) (World Bank, 2016a).

Tourism is also significant for employment as it generates many jobs, particularly in the Caribbean SIDS, where its total contribution to employment in 2015 was more than $30 \%$, compared with $27.9 \%$ in the AIMS and $23.8 \%$ in the Pacific. The average contribution for SIDS as a group was 28.7\% (median 24.3\%), with the highest value in Aruba (90.7\%) and the lowest in Papua New Guinea (1.6\%) (WTTC, 2017b). Moreover, according to UNWTO (2014), tourism has significantly contributed to economic growth and development in some SIDS, particularly Samoa, Cabo Verde, and the Maldives. These three countries are now capable of graduating from the group of the Least Developed Countries (LDCs).

General approaches to tourism flows analysis

According to Naudé and Saayman (2005), the majority of studies on determinants of tourism demand and the international flow of tourism have concentrated on the developed countries. Moreover, Song and Li (2008) stress that there has been insufficient use of panel data analyses in the empirical literature on international tourism demand. Although this has certainly changed over recent years (see particularly Wu et al., 2017, Li et al., 2016, Liu et al., 2018, Pratt \& Liu, 2015), no study so far (to our knowledge) has focused explicitly on investigating factors of tourism flows into SIDS as a group of countries. Therefore, to analyse this, we have decided to employ the dynamic panel data regression based on the gravity approach to explain the determinants of tourism flows into SIDS over the period 1995-2014.

While Song and Li (2008) divide tourism demand modelling and forecasting methods into two general categories (i.e. quantitative and qualitative), Song and Turner (2006) conclude that the majority of studies use the quantitative approach. This can be classified into two broad sub-groups: non-causal time series modelling and causal econometric techniques. The noncausal time series models do not study the relationships between tourism demand and its influencing factors but instead concentrate on explaining a variable with regard to its own past and a random disturbance term. While they are less costly in data collection and represent useful tools for forecasting tourism demand, they cannot be used for policy purposes since they do not identify any causal relationships (Naudé \& Saayman, 2005). Therefore, from a decisionmaking perspective, the econometric causal models applied to time series or panel data can be considered superior since they are constructed based on economic theory (Song et al., 2003). 
However, to estimate these causal models, more advanced econometric approaches must be employed. They are also more data demanding, especially when panel data is used.

Panel data analyses do not have a long history in tourism studies. One of the first was done by Ledesma-Rodríguez et al. (2001), who used both the static and dynamic panel data approach to model the demand for Tenerife tourism. Then, Eilat and Einav (2004) employed the pooled logit regression to identify the determinants of tourism for different regions. Naudé and Sayman (2005) used both cross-sectional data and panel data over 1996-2000 to investigate the determinants of tourist arrivals into 43 African countries. Roget and Gonzales (2006) employed a very similar approach to examine the demand for rural tourism in Galicia. More examples of panel data application for tourism flows analyses can be found within the gravity models approach.

\section{Gravity model approach in tourism literature}

Gravity models have been used since the 1960s, particularly to estimate international trade flows, and they have later been applied in many other fields of international economics to estimate determinants of various kinds of international flows. The basic version of gravity models relates international flows between origin and destination countries to their relative size (in terms of area, population, total GDP, or GDP per capita) and the distance between them. There are, of course, other factors that affect flows between origin and destination countries, such as economic opportunities, political and/or economic stability, freedom and democracy, level of social development, and geographic conditions, which are usually included in the analysis. Dyadic factors such as linguistic or cultural proximity or even policy impacts may be accounted for as well.

According to Fourie and Santana-Gallego (2011a), the main reason for the extensive application of gravity models is their goodness of fit since international flows increase with the (economic or population) size of countries and decrease with the distance between them. That said, the use of gravity models relies on the availability of data for bilateral flows, which in many fields of international economics has only recently become available. Nevertheless, gravity models have been used to estimate determinants of international flows of migrants (Lewer \& Van den Berg, 2008; Ramos \& Suriñach, 2013), goods (Fratianni, 2007; Chaney, 2013), and foreign direct investment (Head \& Ries, 2008).

In the field of international tourism, Gil-Pareja et al. (2007a) used the gravity model framework to estimate the impact of embassies and consulates on tourism. Gil-Pareja et al. (2007b) employed a gravity model approach to study the effect of the European Monetary Union on tourism. Khadaroo and Seetanah (2006) applied the gravity model to investigate tourism flows among 28 countries that were treated both as origins and destinations. Fourie and Santana-Gallego (2011a) investigated the determinants of tourism flows into African countries. The same authors also estimated the impact of sport mega-events on tourist arrivals using gravity models (Fourie \& Santana-Gallego, 2011b). Archibald and LaCorbiniere (2008) used a dynamic gravity model to assess the competitiveness of Caribbean destinations. Culiuc (2014) worked with the gravity framework applied to all available bilateral international tourism flows to estimate the impact of macroeconomic supply-side and demand-side determinants of tourism. His results showed that the gravity model explained tourism flows better than goods trade for the same specifications. 
Analyses of tourism flows in SIDS

Some papers have examined tourism flows into several individual SIDS. Examples include studies by Cassidy and Brown (2010) on Vanuatu; Shareef and McAleer (2008) on the Maldives and Seychelles; Shareef and McAleer (2005) on Barbados, Cyprus, Dominica, Fiji, Maldives, and Seychelles; and Charles and Fullerton (2012) on the Bahamas. However, there have been very few studies that have focused on tourism arrivals into SIDS as a group of destination countries. One reason may be the (un)availability of bilateral tourism and other data related to such a large number of small island economies (see Section 3). Parry and McElroy (2009) compared more-developed Caribbean and less tourism-penetrated Pacific and Indian Ocean islands, using a means difference comparison and the Tourist Penetration Index. They also performed a regression analysis to identify key features of successful small island tourist-driven economies. They found that these features include political dependence, uncrowded ambience, favourable geography, and relative affluence.

Archibald and LaCorbiniere (2008) focused on the tourism competitiveness of Caribbean destinations using a dynamic gravity model. They learned that while tourist arrivals tend to be persistent, the trend can be influenced by changes in the capacity and prices of tourism in the destination relative to the source country and competing destinations as well as fluctuations in exchange rates and airfares. They also found that destination income (as a key indicator of infrastructural development and other aspects of tourism competitiveness) plays a leading role in determining arrivals. Probably the most relevant study for SIDS as a group of destination countries has been done by Ciulic (2014), who devoted part of his analysis to small island destinations. He discovered that tourism to these destinations is less sensitive to changes in the country's real exchange rate but more susceptible to the introduction/removal of direct flights (compared to other destinations).

\section{Data and methods}

To analyse the determinants of tourist arrivals into SIDS, a gravity model framework with dynamic panel data is used. In this section, we describe our dataset as well as our variables. In the second part, we present the methods that were used to estimate the determinants.

\section{Data and variables}

Our dependent variable indicates bilateral tourism flows to 56 destination countries (SIDS) from potentially all possible countries of origins. The inclusion of country pairs (origindestination) in our analysis was defined by the availability of dyadic data for tourism flows for at least one year over 1995-2014 (UNWTO, 2016). Our final dataset contains 3802 country pairs over 20 years, which yield a maximum of 76,040 observations for each variable. However, many observations are missing, as our dependent variable has only 46,532 observations. 
Table 2: Variables, their descriptions, and data sources.

\begin{tabular}{|c|c|c|c|c|}
\hline $\begin{array}{l}\text { Variable } \\
\text { name }\end{array}$ & Description & $\begin{array}{l}\text { Units of } \\
\text { measurement }\end{array}$ & Source of data & $\begin{array}{l}\text { What it approximates; } \\
\text { (expected sign) } \\
\text { Example of a study }\end{array}$ \\
\hline arrivals & $\begin{array}{l}\text { number of tourist arrivals } \\
\text { from an origin country to } \\
\text { a destination }\end{array}$ & number of tourists & UNWTO, 2016 & dependent variable \\
\hline$g d p p c \_d e s t$ & $\begin{array}{l}\text { gross domestic product } \\
\text { per capita of destinations }\end{array}$ & $\begin{array}{l}\text { constant (2011) } \\
\text { international } \\
\text { dollars (PPP) }\end{array}$ & $\begin{array}{l}\text { World Bank, } \\
\text { 2016a }\end{array}$ & $\begin{array}{l}\text { level of destination } \\
\text { development; }(+) \\
\text { Archibald \& LaCorbiniere } \\
(2008)\end{array}$ \\
\hline gdppc_or & $\begin{array}{l}\text { gross domestic product } \\
\text { per capita of countries of } \\
\text { origin }\end{array}$ & $\begin{array}{l}\text { constant (2011) } \\
\text { international } \\
\text { dollars (PPP) }\end{array}$ & $\begin{array}{l}\text { World Bank, } \\
\text { 2016a }\end{array}$ & $\begin{array}{l}\text { income in origin countries; } \\
(+) \\
\text { Gil-Pareja et al. }(2007 b)\end{array}$ \\
\hline pop_dest & $\begin{array}{l}\text { population size of } \\
\text { destinations }\end{array}$ & $\begin{array}{l}\text { number of } \\
\text { inhabitants }\end{array}$ & $\begin{array}{l}\text { World Bank, } \\
\text { 2016a }\end{array}$ & $\begin{array}{l}\text { population in destinations; }(+) \\
\text { Fourie \& Santana-Gallego } \\
\text { (2011a) }\end{array}$ \\
\hline pop_or & $\begin{array}{l}\text { population size of } \\
\text { countries of origin }\end{array}$ & $\begin{array}{l}\text { number of } \\
\text { inhabitants }\end{array}$ & $\begin{array}{l}\text { World Bank, } \\
\text { 2016a }\end{array}$ & $\begin{array}{l}\text { population in origin countries; } \\
(+) \\
\text { Gil-Pareja et al. }(2007 \mathrm{~b})\end{array}$ \\
\hline distance & $\begin{array}{l}\text { air distance between } \\
\text { countries in a pair }\end{array}$ & Kilometres & $\begin{array}{l}\text { Mayer \& Zignago, } \\
2011 \text { (CEPII) }\end{array}$ & $\begin{array}{l}\text { accessibility and/or transport } \\
\text { costs; }(-) \\
\text { Naudé \& Sayman (2005) }\end{array}$ \\
\hline bil_trade_cp & $\begin{array}{l}\text { sum of exports and } \\
\text { imports between countries } \\
\text { in a pair (from } \\
\text { destinations' perspective) }\end{array}$ & $\begin{array}{l}\text { USD, constant } \\
\text { prices of } 2010^{1}\end{array}$ & $\begin{array}{l}\text { United Nations, } \\
2016\end{array}$ & $\begin{array}{l}\text { economic links; }(+) \\
\text { Culiuc (2014) }\end{array}$ \\
\hline pfr_pwt90 & $\begin{array}{l}\text { purchasing power parity } \\
\text { (PPP) factor ratio }{ }^{2}\end{array}$ & $\begin{array}{l}\text { ratio calculated as } \\
\text { the PPP factor of } \\
\text { a destination to } \\
\text { the PPP factor of } \\
\text { an origin country }\end{array}$ & $\begin{array}{l}\text { Feenstra et al., } \\
2015 \text { (PWT 9.0) }\end{array}$ & $\begin{array}{l}\text { real exchange rate; } \\
(-) \\
\text { Culiuc (2014) }\end{array}$ \\
\hline $\mathrm{Col}$ & $\begin{array}{l}\text { common official language } \\
\text { (dummy variable) }\end{array}$ & $\begin{array}{l}\text { equal to one if } \\
\text { countries in a pair } \\
\text { share a common } \\
\text { official language }\end{array}$ & $\begin{array}{l}\text { Melitz \& Toubal, } \\
2014 \text { (CEPII) }\end{array}$ & $\begin{array}{l}\text { cultural affinity; }(+) \\
\text { Fourie \& Santan-Gallego } \\
\text { (2011a) }\end{array}$ \\
\hline colony & $\begin{array}{l}\text { common colonial history } \\
\text { (dummy variable) }\end{array}$ & $\begin{array}{l}\text { equal to one if } \\
\text { countries in a pair } \\
\text { have ever had a } \\
\text { common colonial } \\
\text { link }\end{array}$ & $\begin{array}{l}\text { Head et al., } 2010 \\
\text { (CEPII) }\end{array}$ & $\begin{array}{l}\text { political affinity; }(+) \\
\text { Fourie \& Santana-Gallego } \\
(2011 \mathrm{a})\end{array}$ \\
\hline polstab & $\begin{array}{l}\text { political stability and } \\
\text { absence of violence (sub- } \\
\text { index of the Worldwide } \\
\text { Governance Indicators) }\end{array}$ & $\begin{array}{l}\text { an index ranging } \\
\text { from }-2.5 \text { (lowest) } \\
\text { to } 2.5 \text { (highest) }\end{array}$ & $\begin{array}{l}\text { World Bank, } \\
\text { 2016b }\end{array}$ & $\begin{array}{l}\text { political stability and safety } \\
\text { and security; }(+) \text {; Eilat \& } \\
\text { Einav (2004) }\end{array}$ \\
\hline rooms & $\begin{array}{l}\text { number of hotel rooms in } \\
\text { a destination }\end{array}$ & number of rooms & UNWTO, 2016 & $\begin{array}{l}\text { tourism infrastructure } \\
\text { development; }(+) \\
\text { Khadaroo \& Seetanah (2006) }\end{array}$ \\
\hline wetdays & $\begin{array}{l}\text { number of days with } \\
\text { rainfalls (time-invariant } \\
\text { variable) }\end{array}$ & number of days & $\begin{array}{l}\text { Mitchell et al., } \\
2002\end{array}$ & $\begin{array}{l}\text { weather conditions; } \\
(-) \text {; Gallarza et al., (2002) }\end{array}$ \\
\hline
\end{tabular}

Notes: ${ }^{1}$ In the Comtrade database, trade data is provided in current prices (in USD). Therefore, we use the US GDP deflator data with the base year of 2010 (World Bank, 2016a) to recalculate the trade data to constant USD prices of 2010. ${ }^{2}$ According to Culiuc (2014), there are several standard measures of real exchange rate. In line with most of his study and also because of the availability of data, we work with the PPP factor ratio. It is important to stress, however, that the data is missing for most of the Pacific SIDS. 
We use four groups of independent variables. The first group consists of standard gravity variables: GDP per capita and population size of countries of origin and destinations as well as the distance between countries in the pair. The second group contains two economic relationship variables: bilateral trade and real exchange rate (approximated by the purchasing power parity factor ratio). The third category includes two dummy variables: one for common official language and the other for common colonial history for countries in a pair. In the last group, we lump together three variables that indicate some tourism-relevant features on the destination side: stability and security of the destinations, weather conditions, and tourism infrastructure development. The variables' details, their expected signs, and relevant studies are summarised in Table 2.

\section{Estimation procedure for the gravity approach}

Gravity models can be estimated using the pooled Ordinary Least Squares (OLS) method. This method is simple, but it comes at the costs of ignoring unobserved heterogeneity which, if it is assumed to exist, ultimately leads to inconsistent and inefficient estimates. Therefore, panel data fixed effects estimation procedure could be used to control for the unobserved heterogeneity. Here, the problem would be that the time-invariant variables (for example, distance or the colonial dummy) cannot be estimated. To overcome this problem, the pooled OLS method combined with both destination and origin countries' fixed effects (sometimes years' fixed effects are included as well) can be used to estimate the gravity models (Matyas, Konya and Harris, 2004 or Fourie and Santana-Gallego, 2011a). The inclusion of fixed effects is also used to solve the issue of multilateral resistance when estimating gravity models dealing with flows variable (Anderson \& Van Wincoop, 2004). In this context, it is obvious that the inclusion of country-specific fixed effects is needed not only from the econometric perspective, but also from the gravity model specification point of view.

Dynamics was introduced into gravity models only recently (Martínez-Zarzoso et al., 2009) to solve the fact that some of the flows are highly persistent, which is also assumed to be true for tourist arrivals due to word-of-mouth effects and supply constraints such as shortages of accommodation or limited transportation capacity (Fourie \& Santana-Gallego, 2011a). The inclusion of the lagged dependent variable among the independent variables (i.e. the dynamics) means that the model cannot be estimated by the fixed effects estimator, which would yield biased and inconsistent estimates since the lagged dependent variable is clearly endogenous (it correlates with the error term). This issue can be easily overcome by the application of Arellano-Bond model (Arellano \& Bond, 1991), which uses the first differences-generalised methods of moments estimator (DIF-GMM) or by using the BlundellBond model (Blundell \& Bond, 1998), which employs the system-generalised methods of moments estimator (SYS-GMM). The latter model has been proposed as more appropriate when dependent variables are highly persistent. It also allows for the estimation of effects of time-invariant variables.

The SYS-GMM method is based on the estimation of a system of two equations: the level equation and the first-differences equation. Moreover, it is possible to work with some endogenous independent variables. We consider the lagged dependent variable (GDP per capita of destinations (SIDS)) and the approximation of tourism infrastructure development (In_rooms) as endogenous. In a specification with our bilateral trade variable, we consider this variable to be endogenous as well. 
Originally, we wanted to closely follow Fourie and Santana-Gallego (2011a) and use lagged endogenous regressors as instruments in the first-differenced equation and their lagged first differences as instruments in the level equation. However, because of the results of the AR tests, we had to use deeper lags of the endogenous regressors as instruments in the estimations of the first-differenced and level equations in some of our specifications. We used exogenous variables as standard instruments in both equations (see the bottom part of Table 3 in Section 4). Also, due to the limited number of observations, we had to be cautious and rather parsimonious in the number of instruments we used.

We work with 56 SIDS on the destination side, while the number of country pairs is determined by the availability of data for bilateral tourism flows (UNWTO, 2016). All country pairs for which at least one observation was available through the 20 years under review (1995-2014) have been included in our analysis. We thus work with 3802 country pairs over the 20 -year period, which provides us with a potential maximum of 76,040 observations for each of the variables in our dataset. Although this is not a random sample, since the pairs on which we identify our panel data are defined by data availability, we still think that the analysis has value. Even if we worked with a standardised set of origin countries (and therefore also with a standardised set of country pairs), the pairs excluded from the analysis would be left out on the basis of data unavailability on the dependent variable. The default specification we estimated can be described by the following equation:

$$
\begin{aligned}
& \operatorname{ln\_ arrival} s_{\mathrm{ijt}}=\beta_{0}+\beta_{1} \ln \_ \text {arrivals }_{\mathrm{jit}-1}+\beta_{2} \ln \_g d p p c \_o r_{\mathrm{jt}}+\beta_{3} \ln \_g d p p c \_d e s t_{\mathrm{it}}+
\end{aligned}
$$

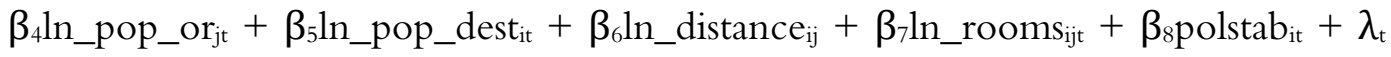

$$
\begin{aligned}
& +\mathrm{u}_{\mathrm{ijt}}(1)
\end{aligned}
$$

In this equation, $i$ indicates destination country, $j$ origin country, and $t$ is time (years); $\beta_{0}$ is the constant, $\beta_{1-8}$ are regression coefficients, $\ln$ is natural logarithm; $\lambda_{t}$ are the year fixed effects, and $\mathrm{u}_{\mathrm{ijt}}$ is well-behaved disturbance term.

\section{Results}

Using the SYS-GMM method, we estimate six models. In the first model, we work with the full sample of country pairs (i.e. with all available data), but we do not include year fixed effects. These are added into the second model. The third model contains also a bilateral trade variable, which is not included in the default specification since it halves the number of observations available. In the final three models, we repeat the second regression (i.e. without the trade variable, but with year dummies) for the different geographic regions of SIDS. The fourth model works only with the Caribbean destinations, the fifth model with AIMS destinations, and the sixth model with Pacific islands.

The default specification (see Equation 1), which is used for the second model and then also applied to the different regions of SIDS, includes the lagged dependent variable, the gravity variables (GDPs per capita and population sizes for destination as well as origin countries and the distance between them), the supply-side variable that represents the tourism infrastructure development (the number of rooms in SIDS), and political stability. We also include variables indicating colonial relationships, language proximity, exchange rate, weather 
conditions, and year fixed effects. In the final model, we have to exclude the supply-side variable as well as the PPP factor ratio (and also the year fixed effects) because of the unavailability of data on these variables for the Pacific islands (otherwise the model could not be estimated due to the small number of observations). Table 3 below presents the results for the aforementioned models.

For the first specification, the results show that all variables are statistically highly significant, and all have the expected signs. The tourism flows into SIDS seem to be highly persistent over time. They depend positively on incomes in countries of origin as well as destination. This shows that, all else being equal, tourists from richer countries of origin prefer economically more-developed island economies. Other gravity variables indicate that there are more tourists from more populous origin countries heading toward more populous SIDS and that the number of tourist arrivals drops with higher distance between countries in a pair, which is used as an approximation of accessibility and travel costs. Infrastructural development in tourism also plays an important role in determining the number of tourists in SIDS: better infrastructure means more arrivals. Stable political environment and absence of violence in destinations is another crucial factor promoting tourism in island economies. More tourist arrivals are also associated with closer historical (colonial) links and with language proximity. The negative coefficient of the PPP factor ratio between an origin and destination country shows that the higher the level of prices of a destination country compared to an origin country price level, the lower the number of tourists. Finally, weather conditions matter as well, indicating that worse weather means (unsurprisingly) lower number of arrivals.

The results change when the year fixed effects are included in the specification (Model 2). While the lag of the dependent variable indicates even higher persistence of tourist arrivals, the effects and significances of other variables are considerably reduced (although all of them keep the expected signs). For example, the effect of GDP per capita of origin countries is now less than half (when compared to the first model) and the same is true for population of origin countries, distance, political stability, colonial links, and language proximity. Some of these variables, as well as population of SIDS, are now significant only at the $5 \%$ level. The most notable change is that the inclusion of year fixed effects renders the supply-side variable (In_rooms) insignificant ( $\mathrm{p}$-value 0.139). However, this result depends on the selection of GMM-type instruments. When deeper lags of the endogenous regressors are added among the GMM-type instruments for the differenced equation, the supply-side variable becomes highly significant once again (p-value 0.001 ) while the other results do not change much.

The inclusion of bilateral trade halves the number of observations in the third model. This is the reason we do not consider this specification as our default. The bilateral trade variable itself is positive and highly significant, which indicates that higher numbers of tourist arrivals are associated with higher bilateral trade flows. The presence of bilateral trade also reduces the effects and significances of other gravity variables in the model. This is particularly true for the GDP per capita of SIDS and the population of SIDS, which become insignificant (moreover, the coefficient for the population variable is now negative). Since this may also be a consequence of collinearity between trade and these variables, we replace population variables by land area of origin and destination countries. However, the results do not change in any practical way. Similarly, the results do not change much when deeper lags of the endogenous regressors (including the bilateral trade variable) are added among the GMMtype instruments for the differenced equation. 
Table 3: Regression models and results.

\begin{tabular}{|c|c|c|c|c|c|c|c|}
\hline \multicolumn{2}{|c|}{ ln_arrivals } & No dummy (1) & Dummy (2) & Trade (3) & Caribbean (4) & AIMS (5) & Pacific (6) \\
\hline \multicolumn{2}{|c|}{ ln_arrivals_L1 (endogenous) } & $\begin{array}{l}0.875^{\star \star \star} \\
(0.017)\end{array}$ & $\begin{array}{l}0.945^{\star \star \star} \\
(0.014)\end{array}$ & $\begin{array}{l}0.799 \star \star \star \\
(0.023)\end{array}$ & $\begin{array}{l}0.541 \star \star \star \\
(0.038)\end{array}$ & $\begin{array}{l}0.921 \star \star \star \\
(0.019)\end{array}$ & $\begin{array}{l}0.889 \star \star \star \\
(0.038)\end{array}$ \\
\hline \multicolumn{2}{|l|}{ ln_gdppc_or } & $\begin{array}{l}0.106^{\star \star \star} \\
(0.020)\end{array}$ & $\begin{array}{l}0.036^{\star \star} \\
(0.015)\end{array}$ & $\begin{array}{l}0.065^{\star \star} \\
(0.029)\end{array}$ & $\begin{array}{l}0.564 \star \star \star \\
(0.062)\end{array}$ & $\begin{array}{l}0.080 \star \star \star \\
(0.024)\end{array}$ & $\begin{array}{l}0.106^{\star \star} \\
(0.046)\end{array}$ \\
\hline \multicolumn{2}{|c|}{ ln_gdppc_dest (endogenous) } & $\begin{array}{l}0.117 \star \star \star \\
(0.023)\end{array}$ & $\begin{array}{l}0.072 \star \star \star \\
(0.021)\end{array}$ & $\begin{array}{l}0.050 \\
(0.038)\end{array}$ & $\begin{array}{l}0.171 \star \star \star \\
(0.056)\end{array}$ & $\begin{array}{l}0.036 \\
(0.024)\end{array}$ & $\begin{array}{l}0.246^{\star \star \star} \\
(0.088)\end{array}$ \\
\hline \multicolumn{2}{|l|}{ ln_pop_or } & $\begin{array}{l}0.101^{\star \star \star} \\
(0.014)\end{array}$ & $\begin{array}{l}0.045^{\star \star \star} \\
(0.011)\end{array}$ & $\begin{array}{l}0.070^{\star \star \star} \\
(0.018)\end{array}$ & $\begin{array}{l}0.334 \star \star \star \\
(0.031)\end{array}$ & $\begin{array}{l}0.070^{\star \star \star} \\
(0.017)\end{array}$ & $\begin{array}{l}0.052^{\star \star \star} \\
(0.016)\end{array}$ \\
\hline \multicolumn{2}{|l|}{ ln_pop_dest } & $\begin{array}{l}0.040^{\star \star \star} \\
(0.014)\end{array}$ & $\begin{array}{l}0.025^{\star \star} \\
(0.013)\end{array}$ & $\begin{array}{l}-0.033 \\
(0.027)\end{array}$ & $\begin{array}{l}0.138^{\star \star \star} \\
(0.042)\end{array}$ & $\begin{array}{l}-0.012 \\
(0.014)\end{array}$ & $\begin{array}{l}0.132^{\star \star \star} \\
(0.040)\end{array}$ \\
\hline \multicolumn{2}{|l|}{ ln_distance } & $\begin{array}{l}-0.225^{\star \star \star} \\
(0.032)\end{array}$ & $\begin{array}{l}-0.099 \star \star \star \\
(0.025)\end{array}$ & $\begin{array}{l}-0.165^{\star \star \star} \\
(0.039)\end{array}$ & $\begin{array}{l}-0.784 \star \star \star \\
(0.071)\end{array}$ & $\begin{array}{l}-0.144 \star \star \star \\
(0.041)\end{array}$ & $\begin{array}{l}-0.244 \star \star \star \\
(0.075)\end{array}$ \\
\hline \multicolumn{2}{|c|}{ ln_rooms (endogenous) } & $\begin{array}{l}0.092 \star \star \star \\
(0.022)\end{array}$ & $\begin{array}{l}0.032 \\
(0.022)\end{array}$ & $\begin{array}{l}0.117 \star \star \star \\
(0.034)\end{array}$ & $\begin{array}{l}0.290 \star \star \star \\
(0.048)\end{array}$ & $\begin{array}{l}0.117 \star \star \star \\
(0.031)\end{array}$ & \\
\hline \multicolumn{2}{|l|}{ Polstab } & $\begin{array}{l}0.061 \star \star \star \\
(0.016)\end{array}$ & $\begin{array}{l}0.029 \star \star \\
(0.014)\end{array}$ & $\begin{array}{l}.089 \star \star \star \\
(0.023)\end{array}$ & $\begin{array}{l}0.098^{\star \star} \\
(0.045)\end{array}$ & $\begin{array}{l}0.062^{\star \star \star} \\
(0.019)\end{array}$ & $\begin{array}{l}0.112^{\star \star} \\
(0.044)\end{array}$ \\
\hline \multicolumn{2}{|l|}{ Colony } & $\begin{array}{l}0.263 \star \star \star \\
(0.049)\end{array}$ & $\begin{array}{l}0.119 \star \star \star \\
(0.036)\end{array}$ & $\begin{array}{l}0.294 \star \star \star \\
(0.075)\end{array}$ & $\begin{array}{l}1.050 \star \star \star \\
(0.144)\end{array}$ & $\begin{array}{l}0.137 \star \star \\
(0.058)\end{array}$ & $\begin{array}{l}0.088^{\star} \\
(0.049)\end{array}$ \\
\hline \multicolumn{2}{|l|}{$\mathrm{Col}$} & $\begin{array}{l}0.134 \star \star \star \\
(0.028)\end{array}$ & $\begin{array}{l}0.041 \star \star \\
(0.020)\end{array}$ & $\begin{array}{l}0.140 \star \star \star \\
(0.038)\end{array}$ & $\begin{array}{l}0.702^{\star \star \star} \\
(0.085)\end{array}$ & $\begin{array}{l}0.047^{\star} \\
(0.028)\end{array}$ & $\begin{array}{l}0.115^{\star \star} \\
(0.046)\end{array}$ \\
\hline \multicolumn{2}{|l|}{ ln_pfr_pwt90 } & $\begin{array}{l}-0.206^{\star \star \star} \\
(0.027)\end{array}$ & $\begin{array}{l}-0.102^{\star \star \star} \\
(0.025)\end{array}$ & $\begin{array}{l}-0.189 \star \star \star \\
(0.034)\end{array}$ & $\begin{array}{l}-.403 \star \star \star \\
(0.061)\end{array}$ & $\begin{array}{l}-0.078^{\star \star \star} \\
(0.029)\end{array}$ & \\
\hline \multicolumn{2}{|l|}{ ln_wetdays } & $\begin{array}{l}-0.082^{\star \star \star} \\
(0.017)\end{array}$ & $\begin{array}{l}-0.049 \star \star \star \\
(0.015)\end{array}$ & $\begin{array}{l}-0.172^{\star \star \star} \\
(0.033)\end{array}$ & $\begin{array}{l}-0.072 \\
(0.149)\end{array}$ & $\begin{array}{l}-0.072^{\star \star \star} \\
(0.020)\end{array}$ & $\begin{array}{l}0.014 \\
(0.073)\end{array}$ \\
\hline \multicolumn{2}{|c|}{ ln_bil_trade_cp ${ }^{\text {(endogenous) }}$} & & & $\begin{array}{l}0.098^{\star \star \star} \\
(0.017)\end{array}$ & & & \\
\hline \multicolumn{2}{|l|}{ _cons } & $\begin{array}{l}-2.057 \star \star \star \\
(0.358)\end{array}$ & $\begin{array}{l}-0.881 \star \star \star \\
(0.323)\end{array}$ & $\begin{array}{l}-0.831 \\
(0.598)\end{array}$ & $\begin{array}{l}-7.244 \star \star \star \\
(1.211)\end{array}$ & $\begin{array}{l}-0.924 \star \star \\
(0.466)\end{array}$ & $\begin{array}{l}-2.883 \star \star \star \\
(1.010)\end{array}$ \\
\hline \multicolumn{2}{|c|}{ No. of observations } & 20757 & 20757 & 11896 & 10833 & 9563 & 1552 \\
\hline \multicolumn{2}{|c|}{ No. of groups } & 1734 & 1734 & 1232 & 980 & 731 & 134 \\
\hline \multicolumn{2}{|c|}{ No. of instruments } & 123 & 159 & 199 & 163 & 159 & 82 \\
\hline \multicolumn{2}{|c|}{ Year Fixed effects } & No & Yes & Yes & Yes & Yes & No \\
\hline \multicolumn{2}{|l|}{$\operatorname{AR}(1)$ test } & $-17.171 \star \star \star$ & $-17.385 \star \star \star$ & $-10.828^{\star \star \star}$ & $-12.505^{\star \star \star}$ & $-11.066^{\star \star \star}$ & $-4.609 \star \star \star$ \\
\hline \multicolumn{2}{|l|}{$\mathrm{AR}(2)$ test } & $4.444 \star \star \star$ & $4.541 \star \star \star$ & 0.390 & 1.411 & 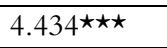 & $2.206^{\star \star}$ \\
\hline \multicolumn{2}{|l|}{$\operatorname{AR}(3)$ test } & -0.373 & -0.343 & 1.364 & 0.916 & -1.541 & $-2.118^{\star \star}$ \\
\hline \multicolumn{2}{|l|}{ AR(4) test } & 0.985 & 0.8756 & 0.657 & 0.466 & 0.571 & 0.667 \\
\hline \multicolumn{8}{|c|}{ Use of Instruments } \\
\hline \multirow[t]{2}{*}{$\begin{array}{l}\text { Differenced } \\
\text { equation }\end{array}$} & $\begin{array}{l}\text { GMM- } \\
\text { type } \\
\text { instruments }\end{array}$ & \multicolumn{2}{|c|}{$\begin{array}{l}\mathrm{L}(2 / 2) \text { of endogenous } \\
\text { independent variables }\end{array}$} & \multicolumn{2}{|c|}{$\begin{array}{l}\mathrm{L}(1 / 1) \text { of endogenous } \\
\text { independent variables }\end{array}$} & $\begin{array}{l}\mathrm{L}(2 / 2) \text { of } \\
\text { endogenous } \\
\text { independen } \\
\mathrm{t} \text { variables }\end{array}$ & $\begin{array}{l}\mathrm{L}(3 / 3) \text { of } \\
\text { endogenous } \\
\text { independent } \\
\text { variables }\end{array}$ \\
\hline & $\begin{array}{l}\text { standard } \\
\text { instruments }\end{array}$ & \multicolumn{6}{|c|}{$\begin{array}{l}\text { first-difference (D.) of exogenous time-variant variables } \\
\text { no-difference of exogenous time-invariant variables }\end{array}$} \\
\hline \multirow[t]{2}{*}{$\begin{array}{l}\text { Level } \\
\text { equation }\end{array}$} & $\begin{array}{l}\text { GMM- } \\
\text { type } \\
\text { instruments }\end{array}$ & \multicolumn{2}{|c|}{$\begin{array}{l}\text { L2D of endogenous } \\
\text { independent variables }\end{array}$} & \multicolumn{2}{|c|}{$\begin{array}{l}\text { LD of endogenous } \\
\text { independent variables }\end{array}$} & $\begin{array}{l}\text { L2.D of } \\
\text { endogenous } \\
\text { independen } \\
t \text { variables }\end{array}$ & $\begin{array}{l}\text { L3.D of } \\
\text { endogenous } \\
\text { independent } \\
\text { variables }\end{array}$ \\
\hline & $\begin{array}{l}\text { standard } \\
\text { instruments }\end{array}$ & exogenous varia & bles & & & & \\
\hline
\end{tabular}

Source: Authors' calculations. Notes: L denotes lags (first lag/last lag), D denotes differences. The presented numbers are regression coefficients estimates, the values in parentheses are Windmeijer bias-corrected (WC) standard errors. $\star \star \star$ denotes statistical significance at $1 \%$ level, $\star \star$ denotes statistical significance at $5 \%$ level, $\star$ denotes statistical significance at $10 \%$ level. AR(.) denotes auto-correlation tests for auto-correlation of a specific order. 
In the remaining three specifications, we repeat the default analysis (Model 2) for the different SIDS regions. Although we originally wanted to apply the exact same specification on all three regions so that the results are directly comparable, there are many observations missing on some of the variables for the Pacific SIDS. For this reason, the supply-side variable (In_rooms), the approximation of the real exchange rate (In_pfr_pwt90), and the year fixed effects do not enter the last model because otherwise the regression analysis could not even be performed due to the small number of available observations. When the results of the three models are compared regardless, it can be found that most of the variables are significant at least at the 5\% level and in the expected directions. However, there are some exceptions to this rule. In the AIMS specification, destination population size and GDP per capita are statistically insignificant, and the dummy for the common official language is significant only at the $10 \%$ level. The latter is also the case for the colonial links dummy in the last specification for the Pacific SIDS.

The majority of regression coefficients in Table 3 can be interpreted as elasticities: they indicate a percentage change in tourist arrivals if a particular explanatory variable changes by one percent (all else being equal). Generally, it is possible to roughly compare the magnitudes of the corresponding coefficients in the three 'regional' specifications. From this perspective, the results suggest that while the arrivals of tourists are highly persistent for the Pacific and AIMS regions, this is not that case for the Caribbean. The effect of GDP per capita in destinations on arrivals is the highest for the Pacific region, followed by the Caribbean, but is low and even insignificant for the AIMS states. The same order holds true with regard to the political stability variable, which, however, is not interpreted as elasticity. The effect of the number of wet days is clearly largest for the AIMS region and is actually the only regional specification in which this variable is significant. Interestingly, the magnitudes of coefficients for all other explanatory variables are highest for the Caribbean region, including the dummy variables for common official language and historical (colonial) links.

\section{Discussion}

Our analysis aims to contribute to understanding the factors that influence tourism demand in SIDS. Small island states are characterised by remoteness, isolation, and limited opportunities for economic development. Because of their small size, the SIDS generally suffer from a lack of mineral and human resources. However, many islands evoke the three 's' (sun, sea, and sand) attributes that are economically useful for tourism promotion. Thus, tourism appears to be one of the (rather few) development opportunities for SIDS, a fact that has been highlighted by several authors and international organisations (e.g. UNWTO, 2014; Prideax \& McNamara, 2012; Sharpley, 2014). An important prerequisite for functional strategies based on increasing tourist arrivals in SIDS is knowledge of the factors that influence these arrivals. Despite considerable heterogeneity within SIDS, we have been able to identify several common factors that are statistically and practically significant to many SIDS. These factors should be of the primary interest to policymakers and decision makers. So what are they?

According to our findings, there is a high persistence in the tourism flows into SIDS. The flows originate in richer countries and aim at the more-developed SIDS (as measured by GDP per capita on origin and destination sides). Similarly, more tourists travel from more populous countries to more populous SIDS. The number of arrivals is negatively influenced 
by travel costs and accessibility of the island destinations (as approximated by the distance variable) and positively influenced by (better) weather conditions. Also, the tourism infrastructure in destinations plays a key role in determining the number of tourists, and the same is true for political stability. The results show as well that language and historical (common colonial links) affinities substantially influence the tourism flows into SIDS. The exchange rate matters too: the more advantageous it is (i.e. the lower the PPP factor of a destination relative to the PPP factor of an origin country), the higher the number of arrivals.

Despite the very different methods of analysis, our results partly support the findings of Parry and McElroy (2009), in which the key determinants of successful small island tourismdriven economies are relative affluence (in terms of GDP per capita in our regression), favourable geography (in terms of weather conditions as well as accessibility), and political affinity. In contrast to their research, we have not found support for the uncrowded ambience hypothesis. Our results also partly support the conclusions of Ciulic (2014), who found that tourism to small island destinations is more dependent on the accessibility of these destinations and less dependent on changes in the country's real exchange rate (compared to others). We have found support for both of these hypotheses, but we have not been able to compare the results to other destinations.

When comparing the different SIDS regions, many similarities and some differences have been found. The tourism flows are highly persistent mainly for the Pacific and AIMS regions. While the level of economic development of destinations can generally be considered a crucial factor, it is not a key determinant of tourism flows for the AIMS region. However, this result is changed to expected and significant when the Maldives (recently an LDC) are excluded from the analysis. Accessibility, exchange rate, tourism infrastructure development, and political stability are also important determinants of tourism flows into all SIDS regions, although it seems that political stability is less crucial for the Caribbean and AIMS regions, perhaps because recently there has not been clear instability in the two regions. Common official language plays a fundamental role in the Caribbean (mainly because of the French departments and former French and British colonies in the region and the proximity of the US), followed by the Pacific (because of the proximity of English-speaking Australia, New Zealand, and the US). In contrast, weather conditions essentially matter only in the AIMS region.

While being informative, our analysis has certain limitations, which can be broadly divided into practical and theoretical areas. One of the most serious constraints to our research is the availability of data. We have included only those pairs of countries for which there was data in the UNWTO database. These were the pairs for which at least one observation on the dependent variable (tourist arrivals) was available over 1995-2014. We have omitted all other pairs that were not included in the UNWTO database. It could have been that all the flows in such pairs were zero flows, but because the UNWTO does not distinguish between zero flows and missing observations, we had to exclude these pairs from our analysis. In the same manner, we had to deal with the missing values on the dependent variable of the included pairs (i.e. the missing values were treated as missing and therefore practically excluded from the analysis). Another issue closely related to the availability of data was the fact that we had to work with different numbers of pairs and observations for different SIDS. This certainly means that those SIDS with the highest number of pairs (observations) available influenced the results the most. It was one of the reasons why we decided to implement the analysis for the SIDS regions separately (apart from the objective to compare the determinants 
of flows for the individual regions of the SIDS). While this shows the importance and also the need of quality and availability of data on tourist arrivals into SIDS, there have been other, more technical and computational issues that required solutions.

For example, the Windmeijer bias-corrected (WC) standard errors have to be used; otherwise the system-generalised methods of moments approach would lead to severely biased results. However, when these robust standard errors are employed, it is not feasible to calculate the Sargan over-identification test to examine whether the set of instruments is weak. This is of course possible when the non-robust standard errors are applied, but then the results of the test may be biased due to potential heteroscedasticity in the data. Therefore, we have relied only on the AR tests when choosing our instruments. Moreover, we have shown that the selection of the sets of instruments may substantially influence the results: when deeper lags of the endogenous variables were included, the results usually improved (in terms of higher statistical significance of most of the variables). At the same time, we had to be parsimonious with regard to the order and range of lags we used for our GMM-type instruments for the differenced equation because, in most of our models, we worked with a (very) limited number of observations. When the range and therefore the number of instruments increased, the models could not have been estimated due to high collinearity.

The theoretical limitations are related to the assumption that tourism is a suitable tool for strengthening economic growth. These are obviously much more complex and certainly beyond the scope of this article. Nevertheless, it should be noted that tourism-based economic development can become a victim of its own success. Clogging a destination with too many tourists can reduce its attractiveness and damage its destination image. At the same time, due to their small size and the presence of fragile ecosystems, the increase in tourism often raises concerns about its impact on local ecosystems and the cultural cohesion of the population of SIDS (Scheyvens \& Momsen, 2008). There is a broad consensus that tourism should not exceed the carrying capacity of islands and coastal environments, but there is much less consensus about how this capacity should be measured and what should be the thresholds for individual island destinations (McElroy \& Albuquerque, 1998; Santana-Jiménez \& Hernández, 2011; Jurado et al., 2013).

In any case, sustainable tourism strategies should weigh financial gains vis-á-vis negative consequences of tourism increase, and politicians should strive to retain income in the destination (Pratt, 2015). Revenues from tourism development should be used not only for renewing the tourist products but also for maintaining the environmental values of the islands. There is evidence that more-developed countries tend to have higher proportions of protected areas (Opršal et al., 2018), and SIDS should not be an exception to this rule. Taleb Rifai, former Secretary-General of the World Tourism Organization, has summed up the challenges of tourism-led development strategies for SIDS: "Tourism can play a key role in a stronger support to the development agenda of the SIDS considering that the sector is the main stay for the economies of many SIDS, and that, due to their vulnerabilities, the SIDS remain a special case for sustainable tourism" (UNWTO, 2014, p. 2).

\section{Conclusion}

We have used the system-generalised methods of moments approach with dynamic panel data within the gravity model framework to examine the determinants of tourism flows into SIDS. 
We have also compared the determinants among the different regional groups of SIDS. Although we faced several limitations, most of which were due to limited data availability, we have verified that the gravity approach combined with the dynamic panel data framework works well for estimations of tourism flows among countries. This is because the gravity model allows us to control the typical gravity determinants of tourism flows as well as many others potential influences (such as the economic relationships variables and cultural, language, and political affinities). At the same time, the dynamic panel data framework, namely the system-generalised methods of moments, handles the high persistency of the dependent variable while allowing the estimation of time-invariant variables' effects.

We have found in our analysis that tourism flows into SIDS are highly persistent indeed and that they depend particularly on the accessibility of destinations, tourism infrastructure, and political stability as well as on the level of economic development of destinations and countries of origin. The exchange rate, language and historical (or political) proximities, and weather conditions also play an important role. While these findings are relevant especially for SIDS as a group of countries, they are also applicable to the various sub-regions of SIDS. The comparison of the determinants of tourism flows has revealed that the same factors are more or less similarly (statistically) significant in the three sub-regions of SIDS and that their importance varies only modestly.

Since the tourism sector represents a crucial source of income for many SIDS, these small island economies simply need to know the factors that influence tourist arrivals. Precisely for this reason, our study is relevant for island economies not only from an analytical standpoint but also from a policy perspective. While we have identified some factors that cannot be effectively managed by policies, such as weather conditions and some of the gravity determinants, it is definitely possible to attract more tourists into SIDS by making the destinations more accessible (more flights or cruises into destinations, which could also lower travel costs), more stable from a political perspective, and generally more economically developed. Moreover, investments into the tourist infrastructure are essential and should be encouraged especially in tourism-based island economies. Likewise, policymakers in many SIDS should consider the exchange rate.

The regional comparisons have revealed that the policy priorities could be slightly different in the different sub-regions of SIDS. While some of them are close to big markets (for example the Caribbean to the US), some others can benefit from language proximities or historical (colonial) affinities. The Pacific SIDS, however, should pay relatively more attention to improvements in political stability. Apparently, such policy recommendations are rather general. This is the consequence of investigating the tourism flows across the SIDS (as a group of countries), while the most relevant policymaking level is the level of individual states. Therefore, case studies of particular SIDS should be regarded as valuable complements to our analysis. 


\section{References}

Anderson, J. E., \& Van Wincoop, E. (2004). Trade costs. Journal of Economic Literature, 42(3), 691-751. https://doi.org/10.1257/0022051042177649

AOSIS (2015). About AOSIS. AOSIS. http://aosis.org/about/

Archibald, X., \& LaCorbiniere, J. (2008). Analysis of tourism competitiveness in the Caribbean: A gravity model approach. Paper presented at the $29^{\text {th }}$ Annual Review Seminar, Central Bank of Barbados.

Arrelano, M., \& Bond, S. (1991). Some tests of specification for panel data: Monte Carlo evidence and an application to employment equations. The Review of Economic Studies, 58(2), 277-297. https://doi.org/10.2307/2297968

Baldacchino, G. (2019). How far can one go? How distance matters in island development. Island Studies Journal, published ahead of print. https://doi.org/10.24043/isj.70

Baldacchino, G., \& Hepburn, E. (2012). A different appetite for sovereignty? Independence movements in subnational island jurisdictions. Commonwealth \& Comparative Politics, 50(4), 555-568. https://doi.org/10.1080/14662043.2012.729735

Blundell, L., \& Bond, S. (1998). Initial conditions and moments restrictions in dynamic panel data models. Journal of Econometrics, 87(1),115-144. https://doi.org/10.1016/s03044076(98)00009-8

Briguglio, L. (1995). Small Island Developing States and their economic vulnerabilities. World Development, 23(9), 1615-1632. https://doi.org/10.1016/0305-750x(95)00065-k

Cañizares, S. M. S., Canalejo, A. M. C., \& Tabales, J. M. N. (2015). Stakeholders' perceptions of tourism development in Cape Verde, Africa. Current Issues in Tourism, 19, 966-980. https://doi.org/10.1080/13683500.2015.1008428

Cassidy, F., \& Brown, L. (2010). Determinants of small Pacific island tourism: a Vanutu study. Asia Pacific Journal of Tourism Research, 15(2), 143-153. https://doi.org/10.1080/10941661003629953

Chaney, T. (2013). The gravity equation in international trade: an explanation. NBER Working Paper No. 19285. Cambridge, MA: National Bureau of Economic Research.

Charles, J. S., \& Fullerton, T. M. (Jr). (2012). Research note: an error correction analysis of visitor arrivals in the Bahamas. Tourism Economics, 18(1), 1-7. https://doi.org/10.5367/te.2012.0101

Culiuc, A. (2014). Determinants of international tourism. IMF Working Paper WP/14/82. International Monetary Fund.

Eilat, Y., \& Einav, L. (2004). The determinants of international tourism: a three dimensional panel data analysis. Applied Economics, 36(12), 1315-1328. https://doi.org/10.1080/000368404000180897

Feenstra, R. C., Inklaar, R., \& Timmer, M. P. (2015). The next generation of the Penn World Table. American Economic Review, 105(10), 3150-3182. https://doi.org/10.1257/aer.20130954

Fratianni, M. (2007). The gravity equation in international trade. Working Papers No. 200717. Indiana: Indiana University, Kelley School of Business.

Fourie, J., Santana-Gallego, M. (2011a). The determinants of African tourism. Working Paper 260. Stellenbosh University and Universitat de les Illes Balears. 
Fourie, J., \& Santana-Gallego, M. (2011b). The impact of mega-events on tourist arrivals. Tourism Management, 32(6), 1364-1370. https://doi.org/10.1016/j.tourman.2011.01.011

Gallarza, M. G., Saura, I. G., \& Garcia, H. C. (2002). Destination image: towards a conceptual framework. Annals of Tourism Research, 29(1), 56-78. https://doi.org/10.1016/s01607383(01)00031-7

Gil-Pareja, S., Llorca-Vivero, R., \& Martínez-Serrano, J. A. (2007a). The impact of embassies and consulates on tourism. Tourism Management, 28(2), 355-360. https://doi.org/10.1016/j.tourman.2006.04.016

Gil-Pareja, S., Llorca-Vivero, R., \& Martínez-Serrano, J. A. (2007b). The effect of EMU on tourism. Review of International Economics, 15(2), 302-312. https://doi.org/10.1111/j.1467-9396.2006.00620.x

Head, K., \& Ries, J. (2008). FDI as an outcome of the market for corporate control: theory and evidence. Journal of International Economics, 74(1), 2-20.

Head, K., Mayer, T., \& Ries, J. (2010). The erosion of colonial trade linkages after independence. Journal of International Economics, 81(1), 1-14. https://doi.org/10.1016/j.jinteco.2010.01.002

Jurado, E. N, Ionela Mihaela Damian, I. M., \& Antonio Fernández-Morales, A. (2013) Carrying capacity model applied in coastal destinations. Annals of Tourism Research, 43, 1-19. https://doi.org/10.1016/j.annals.2013.03.005

Khadaroo, J., \& Seetanah, B. (2008). The role of transport infrastructure in international tourism development: A gravity model approach. Tourism Management, 29 (5), 831-840. https://doi.org/10.1016/j.tourman.2007.09.005

Laframboise, N., Mwase, N., Park, J., \& Zhou, Y. (2014). Revisiting tourism flows to the Caribbean: what is driving arrivals? IMF Working Paper WP/14/229. https://doi.org/10.5089/9781498351560.001

Ledesma-Rodríguez, F. J., Navarro-Ibáñez, M., \& Pérez-Rodríguez, J. V. (2001). Panel data and tourism: A case study of Tenerife. Tourism Economics, 7(1), 75-88. https://doi.org/10.5367/000000001101297748

Lewer, J. J., \& Van den Berg, H. (2008). A gravity model of immigration. Economics Letters, 99(1), 164-167. https://doi.org/10.1016/j.econlet.2007.06.019

Li, H., Chen, J. L., Li, G., \& Goh, C. (2016). Tourism and regional income inequality: Evidence from China. Annals of Tourism Research, 58, 81-99. https://doi.org/10.1016/j.annals.2016.02.001

Liu, H., Li, X., Cárdenas, D. A., \& Yang, Y. (2018). Perceived cultural distance and international destination choice: The role of destination familiarity, geographic distance, and cultural motivation. Journal of Destination Marketing \& Management, 9, 300-309. https://doi.org/10.1016/j.jdmm.2018.03.002

Martínez-Zarzoso, I., Nowak-Lehmann, F., \& Horsewood, N. (2009). Are regional trading agreements beneficial? Static and dynamic panel gravity models. North American Journal of Economics and Finance, 20(1), 46-65. https://doi.org/10.1016/j.najef.2008.10.001

Matyas, L., Konya, L., \& Harris, M. N. (2004). Modelling export activity of eleven APEC countries, 1978-1997. Applied Econometrics and International Development, 4(4), 83-98. 
Mayer, T., \& Zignago, S. (2011). Notes on CEPII's distances measures: the GeoDist database. CEPII Working Paper No. 2011-25. Paris: Centre d'Etudes Prospectives et d'Info Internationales. https://doi.org/10.2139/ssrn.1994531

McElroy, J., \& de Albuquerque, K. (1998). Tourism penetration index in small Caribbean islands. Annals of Tourism Research, 25, 145-168. https://doi.org/10.1016/s0160$\underline{7383(97) 00068-6}$

Melitz, J., \& Toubal, F. (2014). Native language, spoken language, translation and trade. Journal of International Economics, 92(2), 351-363. https://doi.org/10.1016/j.jinteco.2014.04.004

Mitchell, T. D., Hulme, M., \& New, M. (2002). Climate data for political areas. Area, 34(1), 103-112. https://doi.org/10.1111/1475-4762.00062

Naudé, W. A., \& Saayman, A. (2005). Determinants of tourist arrivals in Africa: A panel data regression analysis. Tourism Economics, 11(3), 365-391. https://doi.org/10.5367/000000005774352962

Opršal, Z., Harmáček, J., Pavlík, P., \& Machar, I. (2018). What factors can influence the expansion of protected areas around the world in the context of international environmental and development goals? Problemy Ekorozwoju, 13, 145-157. https://doi.org/10.1016/s1464-2867(01)00018-3

Parry, C. E., \& McElroy, J. L. (2009). The supply determinants of small island tourist economies. Journal of Tourism Research, 2(1), 13-22.

Pelling, M., \& Uitto, J. (2001). Small Island Developing States: Natural disaster vulnerability and global change. Global Environmental Change Part B: Environmental Hazards, 3(2), 4962. https://doi.org/10.1016/s1464-2867(01)00018-3

Pratt, S., \& Liu, A. (2015). Does tourism really lead to peace? A global view. International Journal of Tourism Research, 18(1), 82-90. https://doi.org/10.1002/jtr.2035

Pratt, S. (2015). The economic impact of tourism in SIDS. Annals of Tourism Research, 52, 148-160. https://doi.org/10.1016/j.annals.2015.03.005

Prideax, B., \& McNamara, K. E. (2012). Turning a global crisis into a tourism opportunity: the perspective from Tuvalu. International Journal of Tourism Research, 15(6), 583-594. https://doi.org/10.1002/jtr.1883

Ramos, R., \& Suriñach, J. (2013). A gravity model of migration between ENC and EU. IREA Working Paper No. 2013/17 and AQR Working Paper No. 2013/09. Barcelona: University of Barcelona, Research Institute of Applied Economics (IREA) \& Regional Quantitative Analysis Research Group (AQR).

Roget, F. M., \& Gonzales, X. A. R. (2006). Rural tourism demand in Galicia, Spain. Tourism Economics, 12(1), 21-31. https://doi.org/10.5367/000000006776387178

Santana-Jiménez, Y., \& Hernández, J. M. (2011). Estimating the effect of overcrowding on tourist attraction: The case of Canary Islands. Tourism Management, 32(2), 415-425. https://doi.org/10.1016/j.tourman.2010.03.013

Shareef, R., \& McAleer, M. (2008). Modelling international tourism demand and uncertainty in Maldives and Seychelles: A portfolio approach. Mathematics and Computers in Simulation, 78(2-3), 459-468. https://doi.org/10.1002/jtr.538 
Shareef, R., \& McAleer, M. (2005). Modelling international tourism demand and volatility in small island tourism economies. International Journal of Tourism Research,7(6), 313-333. https://doi.org/10.1002/jtr.538

Sharpley, R. (2014). Tourism and governance in Small Island Developing States (SIDS): The case of Zanzibar. International Journal of Tourism Research, 16, 87-96. https://doi.org/10.1002/jtr.1904

Scheyvens, R., \& Momsen, J. H. (2008). Tourism and poverty reduction: Issues for Small Island States. Tourism Geographies, 10(1), 22-41. https://doi.org/10.1080/14616680701825115

Song, H., \& Li, G. (2008). Tourism demand modelling and forecasting: A review of recent research. Tourism Management, 29(2), 203-220. https://doi.org/10.1016/j.tourman.2007.07.016

Song, H., \& Turner, L. (2006). Tourism demand forecasting. In L. Dwyer \& P. Forsyth (Eds.), International handbook on the economics of tourism. Cheltenham: Edward Elgar.

Song, H., Witt, S. F., \& Jensen, T. C. (2003). Tourism forecasting: Accuracy of alternative econometric models. International Journal of Forecasting, 19(1), 123-141. https://doi.org/10.1016/s0169-2070(01)00134-0

Turvey, R. (2007). Vulnerability assessment of developing countries: The case of Small Island Developing States. Development Policy Review, 25, 243-262. https://doi.org/10.1111/j.1467-7679.2007.00368.x

United Nations (2016). Data from: UN Comtrade database [Dataset]. http://comtrade.un.org/data/

UN (2015). International year of sustainable tourism for development, 2017 (Document no. A/C.2/70/L.5/Rev.1). http://undocs.org/A/C.2/70/L.5/Rev.1.

United Nations (1994). Report of the global conference on the sustainable development of small island developing states, Bridgetown, Barbados, 25 April-6 May 1994 (Report no. A/CONF.167/9). http://www.un.org/esa/dsd/dsd aofw sids/sids pdfs/BPOA.pdf

UN-OHRLLS (2017). Small Island Developing States: Country profiles. UN-OHRLLS. http://unohrlls.org/about-sids/country-profiles/.

UNTWO (2017). UNWTO Annual Report 2016. Madrid: World Tourism Organization. https://doi.org/10.18111/9789284418725

UNWTO (2016). Data from: The Compendium of Tourism Statistics (1995-2014). Excel Datasheets on CD-ROM.

UNWTO (2014). Tourism in Small Island Developing States (SIDS): Building a more sustainable future for the people of islands. Madrid: World Tourism Organization. https://doi.org/10.18111/9789284416257

World Bank (2016a). Data from: World Bank Open Data. https://data.worldbank.org/

World Bank (2016b). Data from: Worldwide Governance Indicators. http://info.worldbank.org/governance/wgi/

WTTC (2017a). Travel \& Tourism Global Economic Impact \& Issues 2017 - March 2017. London: World Travel \& Tourism Council. https://doi.org/10.18111/9789284415960

WTTC (2017b). Data from: World Travel \& Tourism Council Data Gateway. https://tool.wttc.org/ 
Pavla Vitová, Jaromír Harmáček, \& Zdeněk Opršal

Vanegas, M., \& Croes, R. R. (2003). Growth, development and tourism in a small economy: evidence from Aruba. International Journal of Tourism Research, 5, 315-330. https://doi.org/10.1002/jtr.441

Wu, D. C., Song, H., \& Shen, S. 2017. New developments in tourism and hotel demand modeling and forecasting. International Journal of Contemporary Hospitality Management, 29(1), 507-529. https://doi.org/10.1108/ijchm-05-2015-0249 